\title{
Heavy-metal contents in oysters (Crassostrea gigas) cultivated on the southeastern coast of the Gulf of California, Mexico
}

\section{Contenido de metales pesados en ostiones (Crassostrea gigas) cultivados en la costa sureste del Golfo de California, México}

\author{
Andrés Martín Góngora-Gómez', Manuel García-Ulloa' , Norma Patricia Muñoz-Sevilla³, Ana Laura Domínguez-Orozco², Brenda Paulina \\ Villanueva-Fonseca', Juan Antonio Hernández-Sepúlveda² and Rogelio Ortega Izaguirre ${ }^{4}$
}

\begin{abstract}
${ }^{1}$ Instituto Politécnico Nacional (IPN),Departamento de Acuacultura, Centro Interdisciplinario de Investigación para el Desarrollo Integral Regional (CIIDIR), Unidad Sinaloa. Blvd. Juan de Dios Bátiz Paredes \# 250, Guasave, Sinaloa, 81101, México ${ }_{2}^{2}$ PNN. Departamento de Medio Ambiente,CIIDIR, Unidad Sinaloa. ${ }^{3}$ IPN. Laboratoriode Análisis y Monitoreo Ambiental, Centro Interdisciplinario de Investigaciones y Estudios sobre Medio Ambiente y Desarrollo (CIIEMAD), Calle 30 de Junio 1520 s/n, Barrio La Laguna Ticomán, CDMX, 07340. México ${ }_{4}^{4}$ PNN. Departamento de Ingeniería de Desarrollo Sustentable, Centro de Investigación en Ciencia Aplicada y Tecnología Avanzada (CICATA-Tamaulipas), Altamira, Tamaulipas, 89600, México e-mail: turbotuag@hotmail.com

Recibido: 17de noviembre de 2016. Aceptado: 27 de abril de 2017.

Góngora-Gómez A. M., M. García-Ulloa, N. P. Muñoz-Sevilla, A. L. Domínguez-Orozco, B. P. Villanueva-Fonseca, J. A. Hernández-Sepúlveda and R. Ortega Izaguirre. 2017. Heavy-metal contents in oysters (Crassostrea gigas) cultivated on the southeastern coast of the Gulf of California, Mexico. Hidrobiológica 27 (2): $219-227$. DOl: 10.24275/uam/izt/dcbs/hidro/2017v27n2/Garcia
\end{abstract}

\begin{abstract}
Background. For its flesh and flavor, the Pacific oyster Crassostrea gigas is cultivated worldwide, but as filter feeders, this bivalve bioaccumulates heavy metals from different pollution sources, rendering them unsafe for human consumption. Goals. We carried out this study to assess the heavy metal concentrations in cultivated oysters from a farm located on the southeastern coast of the Gulf of California during 2011. Methods. Oyster samples were analyzed monthly (MarchDecember 2011) for cooper (Cu), cadmium (Cd), chromium (Cr), nickel (Ni), lead (Pb), zinc (Zn), arsenic (As), and mercury $(\mathrm{Hg})$. Results. The mean values $\left(\mu \mathrm{g} \mathrm{g} \mathrm{g}^{-1}\right.$, dry weight) for each metal were $\mathrm{Cu}=51.42 \pm 25.92, \mathrm{Cr}=24.97 \pm 32.38, \mathrm{Cd}=$ $13.84 \pm 4.22, \mathrm{Ni}=10.26 \pm 12.18, \mathrm{~Pb}=2.18 \pm 1.28, \mathrm{As}=0.37 \pm 0.08, \mathrm{Zn}=267.42 \pm 92.29$, and $\mathrm{Hg}=0.02 \pm 0.01$. Conclusions. The results suggest that metal burdens could be influenced by anthropogenic activities such as agriculture and aquaculture surrounding the culture zone. $\mathrm{Cu}, \mathrm{Cr}, \mathrm{Cd}$, and $\mathrm{Pb}$ levels ( $\mathrm{gg} \mathrm{g}^{-1}$, fresh weight) were above the maximum permissible values and thus pose a threat to human health. Metal concentrations must be monitored periodically.
\end{abstract}

Key words: Aquaculture, bioaccumulation, Japanese oyster, metal toxicity, pollution.

\section{RESUMEN}

Antecedentes. El ostión del pacífico, Crassostrea gigas, es cultivado en el mundo por su sabor y textura de la carne, pero por ser un organismo que se alimenta mediante filtración, puede acumular metales pesados haciéndolo peligroso para su consumo. Objetivos. El presente estudio evaluó la concentración de metales pesados en ostiones cultivados en una granja localizada en la costa sureste del Golfo de California durante 2011. Métodos. Se tomaron muestras de ostión cada mes (marzo-diciembre 2011) para analizar el contenido de cobre (Cu), cadmio (Cd), cromo (Cr), níquel (Ni), plomo

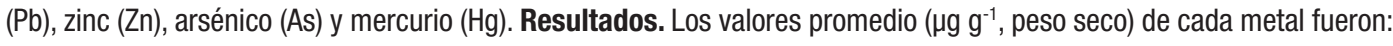
$\mathrm{Cu}=51.42 \pm 25.92, \mathrm{Cr}=24.97 \pm 32.38, \mathrm{Cd}=13.84 \pm 4.22, \mathrm{Ni}=10.26 \pm 12.18, \mathrm{~Pb}=2.18 \pm 1.57, \mathrm{As}=0.37 \pm 0.26$, $\mathrm{Zn}=267.42 \pm 92.29$ and $\mathrm{Hg}=0.02 \pm 0.01$. Conclusiones. Los resultados obtenidos sugieren que la carga de metales pudo haber sido influenciada por actividades antropogénicas desarrolladas en los alrededores del área de cultivo, como agricultura y acuacultura. Los niveles de $\mathrm{Cu}, \mathrm{Cr}$, $\mathrm{Cd}$ y $\mathrm{Pb}$ en peso húmedo rebasaron los límites máximos permitidos representando un riesgo para la salud humana. La carga de los metales estudiados debe ser monitoreada periódicamente.

Palabras claves: Acuacultura, acumulación, contaminación, ostión japonés, toxicidad por metales. 


\section{INTRODUCTION}

Heavy metals leached from soil and rocks to aquatic systems are naturally ubiquitous and pose minimal threats to the environment and human health (Páez-Osuna \& Osuna-Martínez, 2015). Several anthropogenic sources, however, such as agriculture, aquaculture, and mining increase metal burdens exceeding natural levels. Since bivalves accumulate and exhibit efficient strategies to deal with the potential toxic effect of metals (Arifin \& Bendell-Young, 1997), they are used as biomarkers for monitoring metal contamination in aquatic systems (Kanthai et al., 2014).

There are reports from around the world that have used wild and cultured oyster populations from the genus Crassostrea spp. as biomonitors of trace metals. For instance, the spatial pattern of metal accumulation within intertidal bivalves was studied in England to measure the ecological impact of introducing Crassostrea gigas (Thunberg, 1873) in nature mussels (Bray et al., 2015). Sarong et al. (2015) found high levels of $\mathrm{Pb}, \mathrm{Cd}$, and $\mathrm{Zn}$ in the body tissue of $C$. gigas harvested from the estuary of Lamnyong River, Indonesia, and Ochoa et al. (2013) concluded that metallic pollutants did not affect oyster cultures in Ebro Delta, Spain. Concentrations of heavy metals (Cu, $\mathrm{As}, \mathrm{Ni}, \mathrm{Pb}$, and $\mathrm{Cd}$ ) below the maximum levels for foodstuffs in Brazilian legislation were found in the mussel Perna perna Linnaeus, 1758 and $C$. gigas in production areas.

Specifically along the central eastern Gulf of California coast, Mexico, Bergés-Tiznado et al. (2013) evaluated the presence of arsenic compounds in the mangrove oyster Crassostrea corteziensis (Hertlein, 1951). Furthermore, Jara-Marini et al. (2013) compared the bioaccumulation of trace metals in six bivalve species. Analyzing soft tissue of C. gigas from culture sites along the east coast of the Gulf of California, Vázquez-Boucard et al. (2014) found $\mathrm{Zn}, \mathrm{Cd}$, and Pb concentrations above Mexican tolerance levels due to the presence of pesticides.

The Pacific oyster Crassostrea gigas is the most cultivated shellfish species in the world. Its total standing stock in 2013 was 555,994 t (FA0, 2015). It was introduced in Mexico for commercial purposes in the mid-1970s. The Gulf of California is the most important culture region, having registered a significant increase in the last decade from 407.27 t harvested in 2006, to 3,042 t in 2014 (SAGARPA, 2015). This species is mostly reared in estuarine zones where natural productivity is high, thus ensuring its development. At same time, however, these water bodies are continuously exposed to pollutants from natural and human activities that spill out along rivers leading to the gulf. Some pollutants include heavy metals (Páez-Osuna et al., 1991). Several studies in the Gulf of California indicate that various anthropogenic activities such as mining (Cadena-Cárdenas et al., 2009), agriculture, aquaculture (PáezOsuna et al., 2003), and urban development (Ruiz-Luna \& de la LanzaEspino, 1999) are sources of diverse heavy metals.

Compared to other coastal areas of the Gulf of California, such as the east coast (Cadena-Cárdenas et al., 2009) and the northern region (García-Rico et al., 2001), the traditional southeastern oyster-culture areas in the state of Sinaloa are relatively more affected by anthropogenic activities, mostly agriculture. Its agriculture production of vegetables and grain crops make it a region of national importance. It is surrounded by some 350,000 ha of agriculture, forest, animal farms, and more than 50 shrimp farms (Honorable Ayuntamiento de Guasave, 2016). Therefore, these areas are under permanent pressure from an- thropogenic pollutants from various sources located adjacent to the harvesting areas or at a relatively short distance from where oysters are cultured.

Since oysters are sedentary and filter feeders, they are susceptible to metal accumulation and, therefore, are ideal sentinel organisms for assessing environmental pollution along tropical and subtropical coasts (Páez-0suna et al., 1995). Further, this bivalve can be a vector of toxic chemicals for humans because is commonly consumed raw. The information on the levels of heavy metals in oyster species from the southeastern coast of the Gulf of California refers to mangrove $(C$. corteziensis and C. palmula, Carpenter, 1857), and rock C. Iridescens (Hanley, 1854) wild populations (Páez-Osuna et al., 1991, 1993, 2015). There are few studies on cultured oysters (Osuna-Martínez et al., 2010, 2011; Vázquez-Boucart et al., 2014) from different Sinaloa coastal lagoons have compared metal burdens in both rainy and dry seasons. Nevertheless, no information is available on metal concentrations in C. gigas throughout its culture cycle. The presence of high metal levels in cultivated oyster may be an effect of anthropogenic activities, thus indicating a potential risk for human health.

We undertook this investigation to study the status of metal concentrations in cultured Pacific oyster, C. gigas, from a farm located along the southeastern Gulf of California during March-December 2011.

\section{MATERIALS AND METHODS}

Study area. La Pitahaya Estuary (Figure 1) is located on the southeastern coast of the Gulf of California $\left(25^{\circ} 21^{\prime} \mathrm{N}, 108^{\circ} 38^{\prime} \mathrm{W}\right)$, in the state of Sinaloa, Mexico, and is a part of the San-Ignacio-Navachiste-Macapule (SINM) lagoon system. The lagoon system is a marine environment during most of the year due to its two outlets that permanently connect it with the Gulf of California. The lagoon area of SINM has around 22,314 ha, with an estimated population of 91,156 people (Páez-Osuna \& Osuna-Martínez, 2015). Mangrove communities surround La Pitahaya Estuary. The climate of the study area is temperate-subhumid with summer rains (INEGl, 2001). The main activity of the study area is intensive agriculture (105,000 ha) characterized by the use of irrigation with the application of high levels of fertilizers and pesticides (HernándezCornejo et al., 2005; Páez-0suna \& 0suna-Martínez, 2015). Artisanal fishing and well-developed industrial shrimp fisheries are present (Ruiz-Luna \& de la Lanza-Espino, 1999). There are 25 shrimp farms equivalent to 6,621 ha and broiler chickens $(77,785$ chickens/year, Páez-0suna \& Osuna Martínez, 2015).

Experimental animals. Seven thousand Japanese oyster juveniles $(44.78 \pm 7.97 \mathrm{~mm}$ shell height, SH; $5.56 \pm 2.20 \mathrm{~g}$ body weight, BW) were cultured in racks suspended in a long-line system ( $\mathrm{n}=250$ oysters/rack). Oysters were acclimated as mentioned by Gallo-García et al. (2001) and cultivated according to García-Ulloa et al. (2008).

We recorded oyster BW and water quality parameters monthly (March to December 2011). The BW of 50 oysters was measured in situ with a portable balance $(0.00 \mathrm{~g})$. Water temperature and dissolved oxygen, D0, were determined with an oximeter (YSI 55/12FT, Ohio, USA), salinity with a refractometer (ATAG0, S/Mill), pH by using a $\mathrm{pH}$ meter (HANNA, HI 8314, USA), and depth and transparency with a Secchi disk.

Trace metal analysis. Monthly (from March to December 2011), a total of 30 oysters were collected, rinsed with sea water, stored on ice in po- 


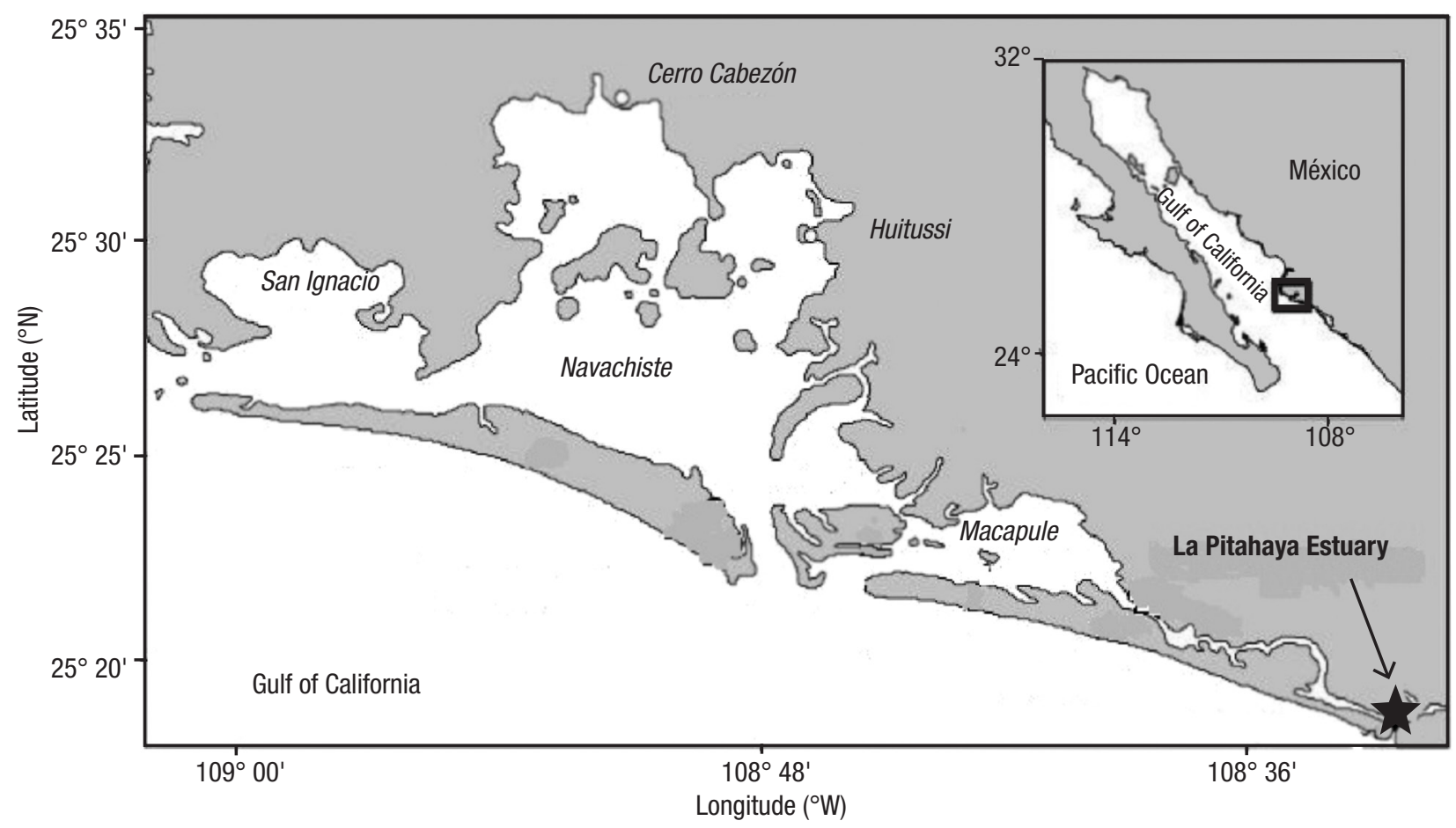

Figure 1. Location of the study area. La Pitahaya estuary (star), part of the San Ignacio-Navachiste-Macapule lagoon system, in Sinaloa, Mexico.

lyethylene plastic bags, and transported to the laboratory for cleaning, sacrificing, and shucking. Thus, a pool of 30 oysters was obtained each month. Oysters were chosen of nearly equal length to limit possible size differences given. Bivalves were opened with a knife to remove soft tissues from the shells and thoroughly washed with double distillated water. Samples were subsequently freeze dried, pulverized in a mortar, and homogenized by quartering, so that all fractions of the sample were equal in composition. The flesh weights and dry weights of the samples were recorded using a digital analytical balance (AE Adam, $0.001 \mathrm{~g}$ ). To avoid metal residues, we used only high-quality reagents (GR grade, Merck Company). All material used were first cleaned with nitric acid (10\%) for a $24 \mathrm{~h}$ period and rinsed with double distillated water.

To analyze metal burdens, each month an aliquot (1.27-1.46 g, dry weight) of oyster sample was digested with $\mathrm{HNO}_{3}$ using a microwave digester (Paar Physica Multiwave Six Place) at $300 \mathrm{~W}$ for 5 min, then at $600 \mathrm{~W}$ for 10 min. $\mathrm{H}_{2} \mathrm{O}_{2}$ was then slowly added to the vessels, which were kept in a hood until all bubbling ceased. The digestion procedure proved satisfactory. Digestion of $\mathrm{Cu}, \mathrm{Cr}, \mathrm{Cd}, \mathrm{Ni}, \mathrm{Pb}, \mathrm{Zn}$, and $\mathrm{Hg}$ were performed in $50 \mathrm{~mL}$ lined digestion vessels, while As was digested in $100 \mathrm{~mL}$ vessels, both equipped with safety relief valves. After digestion, extracts were allowed to cool at room temperature for $25 \mathrm{~min}$ and then diluted to $10 \mathrm{ml}$ with de-ionized water. Digests were stored in labelled polyethylene vials at $0-5{ }^{\circ} \mathrm{C}$ until we performed the metal analysis.

$\mathrm{Cu}, \mathrm{Cr}, \mathrm{Cd}, \mathrm{Ni}, \mathrm{Pb}$, and $\mathrm{Zn}$ were analyzed by atomic absorption spectrophotometry (AAS) with flame (Perkin-Elmer, AAnalyst100), As by AAS with hydride generation, and $\mathrm{Hg}$ by AAS with cold vapor. For quality assurance, the oyster tissue standard reference material sample (1566b for oysters, National Bureau of Standards, NBS), reagent blanks, and duplicate samples were run with each digestion series. Experimental values for all metals (mean recovery) were in good agreement with the NBS certified values (Table 1). Heavy metal concentrations were calculated based on dry weight $\left(\mu \mathrm{g} \mathrm{g}^{-1}\right)$. For each element $(\mathrm{Cu}, \mathrm{Cr}, \mathrm{Cd}, \mathrm{Ni}$, $\mathrm{Pb}, \mathrm{As}, \mathrm{Zn}$, and $\mathrm{Hg}$ ) the detection limits were $0.032,0.032,0.008,0.46$, $0.10,0.002,0.039$, and $0.0003 \mu \mathrm{g} \mathrm{g}^{-1}$ dry weight, respectively.

Statistical analyses. Descriptive statistics (mean, standard deviation, maximum and minimum limits) were used for metal concentrations each month. The coefficient of variation (CV) of metal burdens was used to test the reliability of data with regard to the effect of parameters and BW. Correlations were made with heavy metal levels, BW, and physicchemical parameters. Statistical analyses were performed $(p<0.05)$ using the STATISTICA (StatSoft Inc., Tulsa, OK, USA) software package.

Table 1. Analytical results of standard reference oyster material (1566b) in this study ( $\mu \mathrm{g} g-1$, dry wt), developed in La Pitahaya estuary, Sinaloa, Mexico.

\begin{tabular}{cccc}
\hline Element & $\begin{array}{c}\text { Established } \\
\text { values }\end{array}$ & $\begin{array}{c}\text { Found } \\
\text { values }\end{array}$ & $\begin{array}{c}\text { Mean recovery } \\
(\%)\end{array}$ \\
\hline $\mathrm{Cu}$ & 0.723 & 0.699 & 96.7 \\
$\mathrm{Cr}$ & 18.38 & 20 & 91.2 \\
$\mathrm{Cd}$ & 4.78 & 5 & 95.6 \\
$\mathrm{Ni}$ & 19.46 & 20 & 97.3 \\
$\mathrm{~Pb}$ & 9.38 & 10 & 93.8 \\
$\mathrm{As}$ & 0.09 & 0.1 & 90 \\
$\mathrm{Zn}$ & 957.5 & 1000 & 95.7 \\
$\mathrm{Hg}$ & 0.025 & 0.023 & 93.6 \\
\hline
\end{tabular}


Table 2. Concentration of $\mathrm{Cu}, \mathrm{Cr}, \mathrm{Cd}, \mathrm{Ni}, \mathrm{Pb}, \mathrm{As}, \mathrm{Zn}$, and $\mathrm{Hg}$ (dry and fresh weight, $\mu \mathrm{g} \mathrm{g}{ }^{-1}$; mean, standard deviation, maximum and minimum limits) of cultivated oysters from La Pitahaya, Guasave, Sinaloa, Mexico, during 2011.

\begin{tabular}{lcccccccc}
\hline Month & $\mathrm{Cu}$ & $\mathrm{Cr}$ & $\mathrm{Cd}$ & $\mathrm{Ni}$ & $\mathrm{Pb}$ & $\mathrm{As}$ & $\mathrm{Zn}$ & $\mathrm{Hg}$ \\
\hline Mar. & $<0.032$ & 5.1 & 12.5 & 2 & 0.8 & 0.25 & 138 & 0.038 \\
& $<\mathbf{0 . 0 3 2}$ & $\mathbf{3 . 5 2}$ & $\mathbf{8 . 7 3}$ & $\mathbf{1 . 3 9}$ & $\mathbf{0 . 5 5}$ & $\mathbf{0 . 1 7}$ & $\mathbf{9 6 . 3 6}$ & $\mathbf{0 . 0 2 6}$ \\
Apr. & 43.5 & 0.4 & 17.5 & 2.8 & 3.46 & 0.48 & 215 & 0.003 \\
& $\mathbf{2 9 . 9 6}$ & $\mathbf{0 . 2 9}$ & $\mathbf{1 2 . 0 5}$ & $\mathbf{1 . 9 2}$ & $\mathbf{2 . 3 8}$ & $\mathbf{0 . 3 3}$ & $\mathbf{1 4 8 . 0 8}$ & $\mathbf{0 . 0 0 2}$ \\
May & 26.2 & 41 & 11 & 11 & 1.25 & 0.38 & 170 & 0.003 \\
& $\mathbf{2 0 . 5 8}$ & $\mathbf{3 2 . 2 1}$ & $\mathbf{8 . 6 4}$ & $\mathbf{8 . 6 4}$ & $\mathbf{0 . 9 8}$ & $\mathbf{0 . 2 9}$ & $\mathbf{1 3 3 . 9 7}$ & $\mathbf{0 . 0 0 2}$ \\
Jun. & 34 & 2.4 & 10.5 & 3.7 & 2.25 & 0.4 & 193 & 0.008 \\
& $\mathbf{2 3 . 3 2}$ & $\mathbf{1 . 6 4}$ & $\mathbf{7 . 2 0}$ & $\mathbf{2 . 5 3}$ & $\mathbf{1 . 5 4}$ & $\mathbf{0 . 2 7}$ & $\mathbf{1 3 2 . 3 9}$ & $\mathbf{0 . 0 0 5}$ \\
Jul. & 70 & 22.5 & 21.4 & 10 & 2.25 & 0.44 & 336 & 0.0085 \\
& $\mathbf{5 3 . 1 5}$ & $\mathbf{1 7 . 0 8}$ & $\mathbf{1 6 . 2 4}$ & $\mathbf{7 . 5 9}$ & $\mathbf{1 . 7 0}$ & $\mathbf{0 . 3 3}$ & $\mathbf{2 5 5 . 1 2}$ & $\mathbf{0 . 0 0 6}$ \\
Aug. & 68 & 106 & 14 & 42.6 & 3.45 & 0.33 & 334 & 0.041 \\
& $\mathbf{5 1 . 6 5}$ & $\mathbf{8 0 . 5 2}$ & $\mathbf{1 0 . 6 3}$ & $\mathbf{3 2 . 3 6}$ & $\mathbf{2 . 6 2}$ & $\mathbf{0 . 2 5}$ & $\mathbf{2 5 3 . 7 4}$ & $\mathbf{0 . 0 3 1}$ \\
Sept. & 85 & 7 & 19 & 5 & 1.8 & 0.25 & 418.6 & 0.02 \\
& $\mathbf{5 9 . 3 7}$ & $\mathbf{4 . 8 8}$ & $\mathbf{1 3 . 2 7}$ & $\mathbf{3 . 4 9}$ & $\mathbf{1 . 2 5}$ & $\mathbf{0 . 1 7}$ & $\mathbf{2 9 2 . 4 0}$ & $\mathbf{0 . 0 1 3}$ \\
Oct. & 62.5 & 40.5 & 14 & 13 & 4.6 & 0.3 & 338 & 0.0185 \\
& $\mathbf{4 3 . 0 4}$ & $\mathbf{2 7 . 8 9}$ & $\mathbf{9 . 6 4}$ & $\mathbf{8 . 9 5}$ & $\mathbf{3 . 1 6}$ & $\mathbf{0 . 2}$ & $\mathbf{2 3 2 . 7 9}$ & $\mathbf{0 . 0 1 2 7}$ \\
Nov. & 50.5 & 23 & $\mathbf{9}$ & 11.5 & 0.8 & 0.4 & 230 & 0.02 \\
& $\mathbf{3 9 . 6 7}$ & $\mathbf{1 8 . 0 7}$ & $\mathbf{7 . 0 7}$ & $\mathbf{9 . 0 3}$ & $\mathbf{0 . 6 2}$ & $\mathbf{0 . 3 1}$ & $\mathbf{1 8 0 . 7 1}$ & $\mathbf{0 . 0 1 5}$ \\
Dec. & 74.5 & 1.8 & 9.5 & 1 & 1.2 & 0.46 & 242 & 0.038 \\
& $\mathbf{5 1 . 1 0}$ & $\mathbf{1 . 2 3}$ & $\mathbf{6 . 5 1}$ & $\mathbf{0 . 6 8}$ & $\mathbf{0 . 8 2}$ & $\mathbf{0 . 3 1}$ & $\mathbf{1 6 6}$ & $\mathbf{0 . 0 2 6}$ \\
Mean & 51.42 & 24.97 & 13.84 & 10.26 & 2.18 & 0.37 & 267.42 & 0.02 \\
& $(25.92)^{\dagger}$ & $(32.38)$ & $(4.22)$ & $(12.18)$ & $(1.28)$ & $(0.08)$ & $(92.29)$ & $(0.01)$ \\
& $\mathbf{3 7 . 0 9}$ & $\mathbf{1 8 . 0 1}$ & $\mathbf{9 . 9 8}$ & $\mathbf{7 . 4 0}$ & $\mathbf{1 . 5 7}$ & $\mathbf{0 . 2 6}$ & $\mathbf{1 9 2 . 9 2}$ & $\mathbf{0 . 0 1 4}$ \\
CV \% & 50.4 & 129.6 & 30.4 & 118.7 & 58.7 & 21.6 & 34.5 & 50 \\
Limits & $85-26.2$ & $106-0.4$ & $21.4-9$ & $42.6-1$ & $4.6-0.8$ & $0.48-0.25$ & $418.6-138$ & $0.04-0.003$ \\
\hline
\end{tabular}

${ }^{*}$ Bold numbers $=$ mean fresh weight basis $\left(\mu \mathrm{g} \mathrm{g}^{-1}\right) .{ }^{~}$ Standard deviation.

\section{RESULTS}

The mean water parameters were $26.91 \pm 4.43{ }^{\circ} \mathrm{C}, 6.27 \pm 1.27 \mathrm{mg}$ $\mathrm{L}^{-1}, 33.35 \pm 3.98$ ups, $7.49 \pm 0.48,1.86 \pm 0.29 \mathrm{~m}$, and $0.78 \pm 0.26 \mathrm{~m}$ for temperature, $\mathrm{OD}$, salinity, $\mathrm{pH}$, depth, and transparency, respectively.

The concentration of each metal studied in $C$. gigas varied with the culture time. The highest values were observed as follows: As (0.48 $\left.\mu \mathrm{g} \mathrm{g}^{-1}\right)$ and $\mathrm{Pb}\left(3.46 \mu \mathrm{g} \mathrm{g}^{-1}\right)$ in April; $\mathrm{Cd}\left(21.4 \mu \mathrm{g} \mathrm{g}^{-1}\right)$ in July; $\mathrm{Cr}(106$ $\left.\mu \mathrm{g} \mathrm{g}^{-1}\right)$, Ni $\left(42.6 \mu \mathrm{g} \mathrm{g}^{-1}\right)$, and $\mathrm{Hg}\left(0.041 \mu \mathrm{g} \mathrm{g}^{-1}\right)$ in August; $\mathrm{Cu}\left(85 \mu \mathrm{g} \mathrm{g}^{-1}\right)$ and $\mathrm{Zn}\left(418 \mu \mathrm{g} \mathrm{g}^{-1}\right)$ in September. The mean metal concentrations (N $=10$ ) were $\mathrm{Cu} 51.24 \pm 25.29$; $\mathrm{Cr} 24.97 \pm 32.38, \mathrm{Cd} 13.84 \pm 4.22$, Ni $10.26 \pm 12.18$, Pb $2.18 \pm 1.28$, As $0.37 \pm 0.08$, Zn $267.42 \pm 92.29$, and $\mathrm{Hg} 0.02 \pm 0.01 \mu \mathrm{g} \mathrm{g}^{-1}$, dry weight (Table 2). The metals in the oyster samples showed the following rank order of accumulation: $\mathrm{Zn}>\mathrm{Cu}>\mathrm{Cr}>\mathrm{Cd}>\mathrm{Ni}>\mathrm{Pb}>\mathrm{As}>\mathrm{Hg}$.

Correlation analyses for metal levels, BW, and parameters (Table 3) showed a positive correlation of $\mathrm{Cd}, \mathrm{Ni}, \mathrm{Pb}, \mathrm{Zn}, \mathrm{Cu}$, and $\mathrm{Cr}$ with $\mathrm{BW}$ and $\mathrm{T}$
${ }^{\circ} \mathrm{C}$, but a negative correlation of $\mathrm{Cr}, \mathrm{Ni}, \mathrm{Pb}$, and $\mathrm{Zn}$ with $\mathrm{pH}$ and $\mathrm{DO}$. Only the $\mathrm{BW} / \mathrm{T}{ }^{\circ} \mathrm{C}$ and depth/transparency were positively correlated. Strong correlations were obtained for $\mathrm{Cr} / \mathrm{Ni}$, Cu/Zn, and $\mathrm{Cd} / \mathrm{Zn}$.

\section{DISCUSSION}

The results of metal analysis showed that the concentrations of these eight elements in $C$. gigas reared at the La Pitahaya estuary, Sinaloa, varied monthly. Mean values of $\mathrm{Cu}$ and $\mathrm{Cd}$ burdens were higher when compared to other studies in Mexico but lower when compared to other countries (Table 4). Some trace metals are essential for normal development of mollusks (Bryan, 1971). Zn, Na, and K are needed for tissue formation and metabolic physiology, while $\mathrm{Fe}, \mathrm{Cu}$, and $\mathrm{Al}$ are involved in cellular metabolism, protein synthesis, and lipid/carbohydrate metabolism (Barile, 2008). Levels higher than these requirements, however, may cause physiological damage that could threaten growth performance. In this study, oyster BW showed a constant increase until July. 
However, with the exception of $\mathrm{As}$ and $\mathrm{Pb}$, the remaining metal levels decreased from July to September. Loss of metals in soft tissue could be attributed to a combined effect of water salinity dilution during the rainy season (July to September) and spawning (Robinson et al., 2005; Le et al., 2015), which affect the metal levels by decreasing the concentrations. Jara-Marini et al. (2013) mention that Cu levels in adult oysters decrease during the post-spawning event and Lango-Reynoso et al. (2010) observed that variations of $\mathrm{Cd}$ accumulation in $C$. virginica (Gmelin, 1791) are a result of different stages of reproduction, among other factors. This suggests that oysters accumulated metals as their BW increased until the rainy season, which induced them to spawn and, consequently, caused the BW and metal levels to decrease. In wild populations, fluctuations in the trace metal levels of cultured oysters depend on several factors, such as the season. For instance, PáezOsuna et al. (1995) concluded that levels of some metals vary seasonally with gonad maturation, while Páez-0suna \& Marmolejo-Rivas (1990a, 1990b), and Páez-Osuna et al. (1995) found higher levels of Cu and $\mathrm{Zn}$ at the end of the reproductive cycle of several oyster species. These previous findings coincide with our results since the higher metal levels were obtained after the oysters reached their highest BW (JulyAugust). As Páez-Osuna et al. (1995) determined, some metal concentrations $(\mathrm{Cu}, \mathrm{Cd}, \mathrm{Cr}, \mathrm{Ni}, \mathrm{Zn}$, and $\mathrm{Hg}$ ) during the oyster pre-spawning period (June) were low due to dilution of metals in the soft tissue as the BW increased.

Metal concentrations in C. gigas cultivated at La Pitahaya estuary were initially sampled when oysters had a shell height around 35-45 $\mathrm{mm}$ (3-4 months after culture started), coinciding with the specimen size collected by Páez-0suna et al. (1991) for analyzing trace metals in different bivalve species. In this study, the ranking of metal concentrations in C. gigas reflects the typical metal accumulation of other Crassostrea species (Phillips \& Muttarasin, 1985; Páez-Osuna \& MarmolejoRivas, 1990a; Lin \& Hsien, 1999), for which Zn posted the highest level and $\mathrm{Hg}$ the lowest.

Osuna-Martínez et al. (2010) and Ochoa et al. (2013) highlighted the importance of oyster depuration prior to being analyzed for heavy metal concentration in order to eliminate digested and undigested food and other particles from gut contents with a potentially high-trace metal burden. This procedure allows us to quantify metal accumulation in body tissue. In our case, $C$. gigas was not depurated for analytical purposes since, first, such a procedure is not a common practice among local farmers and vendors; second, this bivalve is consumed raw.

Different national and international metal regulation for seafood with a fresh weight basis establish the following limits: $\mathrm{Cu}=32.5 \mu \mathrm{g} \mathrm{g}^{-1}$ (FA0, 1983), $\mathrm{Cr}=13 \mu \mathrm{g} \mathrm{g}^{-1}$ (FDA, 2003), $\mathrm{Cd}=0.5 \mu \mathrm{g} \mathrm{g}^{-1}$ (NOM, 1993), $\mathrm{Ni}=80 \mu \mathrm{g} \mathrm{g}^{-1}$ (FDA, 2003), $\mathrm{Pb}=1 \mu \mathrm{g} \mathrm{g} \mathrm{g}^{-1}$ (NOM, 1993), As $=80 \mu \mathrm{g} \mathrm{g}^{-1}$ (NOM, 1993), Zn = $718 \mu \mathrm{g} \mathrm{g}^{-1}$ (FDA, 1993), and $\mathrm{Hg}=1 \mu \mathrm{g} \mathrm{g} \mathrm{g}^{-1}$ (NOM, 1993). The values of $\mathrm{Cu}, \mathrm{Cd}, \mathrm{Cr}$, and $\mathrm{Pb}$ surpassed permissible concentrations. The $\mathrm{Cd}, \mathrm{Cu}, \mathrm{Zn}, \mathrm{Pb}$, and As burdens were higher compared to those reported by García-Rico et al. (2001) for $C$. gigas cultured on the northwestern Gulf of California coast $(0.95,4.55,22.75,0.62$, and $0.06 \mu \mathrm{g} \mathrm{g}^{-1}$, respectively). Also, $\mathrm{Cd}, \mathrm{Cu}$, and $\mathrm{Pb}$ were higher than the levels obtained by Najiah et al. (2008) for $C$. iredalei (Faustino, 1932) cultivated in Malaysia $\left(1.60,38.9\right.$, and $0.17 \mu \mathrm{g} \mathrm{g}^{-1}$, respectively) and by Ochoa et al. (2013) rearing C. gigas in Spain $(0.5,38.83$, and $0.26 \mu \mathrm{g}$ $\mathrm{g}^{-1}$, respectively). Yet the levels of $\mathrm{Cu}, \mathrm{Ni}$, and $\mathrm{Pb}$ were lower compared to those reported by Cadena-Cárdenas et al. (2009) (181, 12.2, and 5.8 $\mu \mathrm{g} \mathrm{g}{ }^{-1}$, respectively) for several species of clams and mussels sampled along the Gulf of California. Differences can be attributed to the specific environmental conditions at those latitudes, human activities surrounding the sampled area, and the species studied, among other factors.

García-Rico et al. (2001) and Robinson et al. (2005) indicate that a consistent association between particular groups of metals may reflect their common metabolic route. $\mathrm{Cu}, \mathrm{Cd}, \mathrm{Ni}$, and $\mathrm{Zn}$ posted the highest correlation values among the metals since they are mostly related with anthropogenic activities (Jara-Marini et al., 2013). Some fertilizers such as Agrinutriente Micromax, Agrinutriente $\mathrm{Cu}$ and Agrinutriente $\mathrm{Zn}$, and the fungicides based on zinc ethylene-bis-dithiocarbamate (Zineb) and cooper oxychloride (Cupravit) are commonly used in the region (PáezOsuna et al., 1993) reflecting their source, since such compounds contain $\mathrm{Cu}$, Ni, and Zn. The SINM lagoon system is connected to the DR 075 and DR 063 Río Sinaloa irrigation districts and receives agrochemicals mainly from agriculture and aquaculture. Escobedo-Urías (2010) estimated that the SINM received $1243.10 \mathrm{t}$ of inorganic nitrogen and $37 \mathrm{t}$ of inorganic phosphorous from anthropogenic activities in 2007. In the same year, Gómez-Arroyo et al. (2013) reported that $6500 \mathrm{t}$ of captan (pentachlorophenol-based fungicide) were applied in 5000 ha of cultures, in northern Sinaloa, among other insecticides (chlorpyrifos, Malathion, carbaryl cypermethrin), herbicides (atrazine, paraquat, mancozeb), and fungicides (cupravit, maneb, benomyl). For example, $121737 \mathrm{t}$ of metam-sodium (dithiocarbamate) and cadusafes (organophosphorus) were applied at the tomato plantations in Culiacan Valley, Sinaloa, during the 2011-2012 culture cycle. The agrochemicals are eventually leached from the soil and transported to the coastal zones where oyster farms are located, and therefore oysters could be exposed to these metals. As for $C$. corteziensis in the same lagoon system, $\mathrm{Zn}$

Table 3. Spearman rank order correlations ( $r$ ) for metal levels ( $\mathrm{Cu}, \mathrm{Cr}$, $\mathrm{Cd}, \mathrm{Ni}, \mathrm{Pb}, \mathrm{As}, \mathrm{Zn}$, and $\mathrm{Hg}$ ), oyster weight, environmental parameters ( $\mathrm{T}$ ${ }^{\circ} \mathrm{C}$, depth, pH, salinity, D0 and transparency) and between metals, in cultivated $C$. gigas from La Pitahaya, Sinaloa, Mexico, during MarchDecember 2011.

\begin{tabular}{|c|c|c|c|c|c|}
\hline \multicolumn{2}{|c|}{ Metal/BW/Parameters } & \multicolumn{2}{|c|}{ BW/Parameters } & \multicolumn{2}{|c|}{ Metal/Metal } \\
\hline BW vs. Cd & 0.66 & $\mathrm{BW}$ vs. $\mathrm{T}^{\circ} \mathrm{C}$ & 0.80 & Cu vs. Cd & 0.64 \\
\hline $\mathrm{BW}$ vs. Ni & 0.57 & BW vs. DO & -0.85 & Cu vs. Zn & 0.93 \\
\hline BW vs. $\mathrm{Pb}$ & 0.69 & $\mathrm{~T}^{\circ} \mathrm{C}$ vs. $\mathrm{pH}$ & -0.56 & $\mathrm{Cu}$ vs. $\mathrm{Hg}$ & 0.64 \\
\hline BW vs. Zn & 0.58 & $\mathrm{~T}^{\circ} \mathrm{C}$ vs. DO & -0.72 & Cd vs. $\mathrm{Pb}$ & 0.59 \\
\hline $\mathrm{T}^{\circ} \mathrm{C}$ vs. $\mathrm{Cu}$ & 0.63 & pH vs. Sal. & -0.65 & Cd vs. Zn & 0.75 \\
\hline $\mathrm{T}^{\circ} \mathrm{C}$ vs. $\mathrm{Cd}$ & 0.79 & D0 vs. Trans. & -0.67 & Cr vs. Ni & 0.96 \\
\hline $\mathrm{T}^{\circ} \mathrm{C}$ vs. $\mathrm{Cr}$ & 0.73 & Depth vs. Trans & 0.62 & Cr vs. Zn & 0.56 \\
\hline $\mathrm{T}^{\circ} \mathrm{C}$ vs. $\mathrm{Ni}$ & 0.77 & & & $\mathrm{Ni} v s . \mathrm{Pb}$ & 0.55 \\
\hline $\mathrm{T}^{\circ} \mathrm{C}$ vs. $\mathrm{Pb}$ & 0.69 & & & Ni vs. Zn & 0.59 \\
\hline $\mathrm{T}^{\circ} \mathrm{C}$ vs. $\mathrm{Zn}$ & 0.82 & & & $\mathrm{Zn}$ vs. $\mathrm{Hg}$ & 0.56 \\
\hline $\mathrm{pH}$ vs. Cr & -0.59 & & & & \\
\hline $\mathrm{pH}$ vs. Ni & -0.66 & & & & \\
\hline DO vs. Cr & -0.63 & & & & \\
\hline DO vs. Ni & -0.61 & & & & \\
\hline $\mathrm{DO}$ vs. $\mathrm{Pb}$ & -0.55 & & & & \\
\hline $\mathrm{DO}$ vs. Zn & -0.60 & & & & \\
\hline
\end{tabular}

Only significant correlations $(p<0.05)$ are included. 
and Cu concentrations in $C$. gigas may be due to the use of Cu- and Zn-based agriculture products (Páez-Osuna \& Osuna-Martínez, 2015), as well as the use and application rates of feed additives, liming materials, inorganic fertilizers, and antibiotics applied in the shrimp farms. Lyle-Fritch et al. (2006) identified 106 different types of products, and approximately 42 products that are commonly applied at shrimp farms. As, essential element for normal growth and development (Ochoa et al., 2013), Cu is present in aquatic invertebrates and its bioaccumulation can increase with size (Pan \& Wang, 2009). The consumption of oysters with high Cu levels can cause irritation, vomiting, and ulcer and kidney damage (ATSDR, 2004). Gorman (1993) indicates that high levels of $\mathrm{Cu}$ could even stunt human growth. $\mathrm{Cr}$ is an essential micronutrient trace metal that has a similar pattern to $\mathrm{Ni}$ and $\mathrm{Zn}$, and, in humans, $\mathrm{Cr}$ is an essential part of the glucose tolerance factor (Cheung \& Wong, 1992). Its excess, however, may led to diabetes, may lead to diabetes. Cadmium is a nonessential metal for organisms, highly toxic to wildlife, and carci-

Table 4. Metal concentrations ( $\left.\mu \mathrm{g} \mathrm{g}{ }^{-1} \mathrm{~d} . w.\right)$ in wild and cultured oysters from various countries and the Gulf of California, Mexico.

\begin{tabular}{|c|c|c|c|c|c|c|c|c|c|}
\hline $\mathrm{Cu}$ & $\mathrm{Cd}$ & $\mathrm{Cr}$ & $\mathrm{Ni}$ & $\mathrm{Pb}$ & $\mathrm{Zn}$ & As & $\mathrm{Hg}$ & sp., location, year & Reference \\
\hline $17.5-166.3$ & $1.5-7.4$ & ND & ND & $4.1-9.4$ & $245-2304$ & & ND & Cc, CLSEGC, 2005 & $\begin{array}{l}\text { Frías-Espericueta } \\
\text { et al. (2009) }\end{array}$ \\
\hline $15.4-216$ & ND & ND & ND & $3.6-7.6$ & $442-1595$ & & ND & $\begin{array}{l}\text { Cc, CLSEGC, } \\
1997-1998\end{array}$ & $\begin{array}{l}\text { Páez-Osuna et al. } \\
\text { (2002) }\end{array}$ \\
\hline $33.6-44.9$ & $0.2-0.6$ & ND & ND & $0.3-1.9$ & $263-382$ & & $0.03-0.08$ & $\begin{array}{l}\text { Cc, Estuary Urías } \\
\text { Lagoon, } 2006\end{array}$ & $\begin{array}{l}\text { Jara-Marini et al. } \\
(2008)\end{array}$ \\
\hline $1.7-3.5$ & $0.9-4.9$ & ND & ND & $0.4-0.7$ & ND & & $0.03-0.04$ & $\begin{array}{l}\text { Cc, Bacochibampo } \\
\text { Lagoon, Sonora, } \\
2006\end{array}$ & $\begin{array}{l}\text { García-Rico et al. } \\
\text { (2010) }\end{array}$ \\
\hline 23.1-112.6 & $1.0-9.0$ & ND & ND & $0.3-2.1$ & $226-1745$ & & $0.17-0.57$ & $\begin{array}{l}\text { Cc, CJSEGC, } \\
2008-2009\end{array}$ & $\begin{array}{l}\text { Páez-Osuna- } \\
\text { Osuna-Martínez } \\
\text { (2015) }\end{array}$ \\
\hline \multirow[t]{3}{*}{$33.9-46.0$} & 0.27 & ND & ND & $0.5-1.8$ & $254.3-348$ & & ND & $\begin{array}{l}\text { Cc, Estuary Urías, } \\
2006\end{array}$ & $\begin{array}{l}\text { Jara-Marini et al. } \\
\text { (2009) }\end{array}$ \\
\hline & & ND & ND & & ND & $5.2-11.6$ & ND & $\begin{array}{l}\text { Cc, CLSEGC, } \\
2008-2009\end{array}$ & $\begin{array}{l}\text { Bergés-Tiznado } \\
\text { et al. (2013b) }\end{array}$ \\
\hline & & ND & ND & & $36.6-1702$ & & $0.2-0.6$ & $\begin{array}{l}\mathrm{Cc} / \mathrm{Cg} \text {, Tobari } \\
\text { Lagoon, CEGC, NA }\end{array}$ & $\begin{array}{l}\text { Jara-Marini et al. } \\
\text { (2013) }\end{array}$ \\
\hline \multirow[t]{4}{*}{$9.1-58.0$} & $4.9-13.9$ & ND & ND & $0.5-2.1$ & $113-478$ & & ND & $\mathrm{Cg}, \mathrm{CLSEGC}, \mathrm{NA}$ & $\begin{array}{l}\text { Osuna-Martínez } \\
\text { et al. (2011) }\end{array}$ \\
\hline & $4.2-7.3$ & ND & ND & $7.2-9.9$ & $405.5-987.5$ & & ND & $\mathrm{Cg}, \mathrm{ECGC}, \mathrm{NA}$ & $\begin{array}{l}\text { Vázquez-Boucard } \\
\text { et al. (2014) }\end{array}$ \\
\hline & & ND & ND & & ND & & $0.06-0.91$ & $\mathrm{Cg}, \mathrm{CLSEGC}, \mathrm{NA}$ & $\begin{array}{l}\text { Osuna-Martínez } \\
\text { et al. 2010) }\end{array}$ \\
\hline & & ND & ND & & ND & & 0.23 & $\begin{array}{l}\text { Cg, Guaymas } \\
\text { Lagoon, NA }\end{array}$ & $\begin{array}{l}\text { Green-Ruiz et al. } \\
\text { (2005) }\end{array}$ \\
\hline $26.2-85.0$ & $9.0-21.4$ & $0.4-06.0$ & $1.0-42.6$ & $0.8-4.6$ & $138.0-418.6$ & $0.25-0.48$ & $0.003-0.04$ & $\begin{array}{l}\text { Cg, Estuary La } \\
\text { Pitahaya,SEGC, } \\
2011\end{array}$ & This study \\
\hline 391.36 & 2.19 & ND & ND & 1.14 & 1972.17 & ND & ND & $\begin{array}{l}\text { Cg, SE England } \\
2007-2008\end{array}$ & Bray et al. (2015 \\
\hline 100 & 2.0 & ND & ND & ND & 2237 & ND & ND & $\begin{array}{l}\text { Cg, Arcachon, } \\
\text { France, NA }\end{array}$ & $\begin{array}{l}\text { Table } 1 \text { of } \\
\text { Bragigand et al. } \\
(2004)\end{array}$ \\
\hline 1041 & 7.5 & ND & ND & ND & 4964 & ND & ND & $\begin{array}{l}\mathrm{Cg} \text {, Gironde } \\
\text { Estuary, France, } \\
\mathrm{NA}\end{array}$ & $\begin{array}{l}\text { Table } 1 \text { of } \\
\text { Bragigand et al. } \\
(2004)\end{array}$ \\
\hline ND & $0.01-0.15$ & ND & ND & 0.019 & $3.7-11.5$ & ND & ND & $\begin{array}{l}\text { Cg, Estuary of } \\
\text { Lamnyong River, } \\
\text { Indonesia, } \\
2013-2014\end{array}$ & $\begin{array}{l}\text { Sarong et al. } \\
(2015)\end{array}$ \\
\hline
\end{tabular}

$C c=$ Crassostrea corteziensis; $C g=$ Crassostrea gigas; $N D=$ not determined; NA = not available; CLSEGC = coastal lagoons from Southeast Gulf of California; ECGC $=$ East Coast Gulf of California; SEGC $=$ Southeast Gulf of California; CEGC $=$ Central East Gulf of California. 
nogenic to humans (Wong et al., 1981) since it tends to accumulate in the liver and kidney (Abbe et al., 2000). Páez-Osuna \& Osuna-Martínez (2015) concluded that high $\mathrm{Cd}$ levels in the tissue of $C$. corteziensis from SINM could be related to upwelling events, rather than wastes derived from anthropogenic activities, which could partially explain the $\mathrm{Cd}$ burdens bioaccumulated by $C$. gigas in this study. In addition, the authors pointed out that closely related oyster species living in the same site can accumulate significantly different levels of metals. Although $\mathrm{Pb}$ is known to be a metabolic poison, low concentrations are often observed in shellfish due to the dietary and dissolved lead available for marine invertebrates (Amiard et al., 1986). Higher levels of Pb in oysters can be due to the river runoff and erosion of this metal from the natural bed rock in the region (Soto-Jiménez et al., 2001), as well as human activities such as tourism, fisheries, and untreated urban sewage, i.e., potential pollution sources. In this case, the pollution status of the SINM lagoon system, where La Pitahaya Estuary is located, is well documented, particularly for heavy metals derived from human activities (Hernández-Cornejo et al., 2005; Escobedo-Urías, 2010; Páez-Osuna \& Osuna-Martínez, 2015), which helps to explain the results we obtained.

Based on the metal levels obtained, we conclude that cultivated oysters from La Pitahaya Estuary accumulated $\mathrm{Cu}, \mathrm{Cd}, \mathrm{Cr}$, and $\mathrm{Pb}$ above the permissible limits for human consumption during the 2011 production cycle, thus posing a human-health risk. However, the apparent exposure of metals may not involve a consistent intake since individuals consume oysters occasionally. Due to the intense anthropogenic activity and the significant population in the area, the economic importance of the species, and the public-health concerns regarding raw consumption of oysters, we suggest that studies of heavy-metal concentrations in $C$. gigas farmed in this region be carried out periodically. Depuration, moving oyster racks to lower metal levels sites, and use of sterilized water to clean oysters before consumption are also possible strategies in lowering metal contents (Okazaki \& Panietz, 1981; Katayon et al., 2007; Wang \& Wang, 2014).

\section{ACKNOWLEDGMENTS}

The authors wish to express their gratitude to the Instituto Politécnico Nacional (IPN), the Secretaría de Investigación y Posgrado (SIP-IPN), and the Comisión de Operaciones y Fomento de Actividades Académicas (COFAA-IPN) for financial support for the SIP-IPN 1695 multidisciplinary project (Efecto de los metales pesados en organismos triploides de ostión japonés Crassostrea gigas cultivados en Ensenada Pabellones, Navolato, Sinaloa.)

\section{REFERENCES}

Abbe, G. R., G. F. Riedel \& J. G. Sanders. 2000. Factors that influence the accumulation of cooper and cadmium by transplanted eastern oysters Crassostrea virginica in the Patuxent river, Maryland. Marine Environmental Research 49 (4): 377-396. D0I:10.1016/S01411136(99)00082-3

Amiard, J. C., C. Amiard-Triquet, B. Berthet \& C. Metayer. 1986. Contribution to the ecotoxicological study of cadmium, lead, cooper and zinc in the mussel: Mytilus edulis. Marine Biology 90 (3): 425-431. DOI:10.1007/BF00428566
ARIFIN, Z. \& L. I. BeNDELL-Young. 1997. Feeding response and carbon assimilation by the blue mussel Mytilus trossulus exposed to environmentally relevant seston matrices. Marine Ecology Progress Series 160: 241-253.

ATSDR (Agency for Toxic Substances \& DiseAse Registry). 2004. Toxicological profile for cooper. Atlanta, GA: Departamento de Salud y de Servicios Humanos de EUA. Servicio de Salud Pública. [Actualizado en el 2007]. Página electrónica (www.atsdr.cdc.gov/es/phs/es_ph132. $\mathrm{html})$

Barile, F. 2008. Principles of Toxicology Testing. CRC Press, Boca Ratón, FL.

Bergés-Tiznado, M. E., F. Páez-Osuna, A. Notti \& F. Regoli. 2013a. Biomonitoring of arsenic through mangrove oyster (Crassostrea corteziensis Hertlien, 1951) from coastal lagoons (SE Gulf of California): occurrence of arsenobetaine and other arseno-compounds. Environmental Monitoring and Assessment 185: 7459. D0I: 10.1007/ s10661-013-3112-8

Bergés-Tiznado, M. E., F. Páez-Osuna, A. Nottı \& F. Regolı. 2013b. Arsenic and arsenic species in cultured oyster (Crassostrea gigas and C. corteziensis) from coastal lagoons of the SE Gulf of California, Mexico. Biological and Trace Element Research 151: 43-49. D0l:10.1007/s12011-012-9536-0

Bragigand, V., B. Berthet, J. -C. Amiard \& P. S. Rainbow. 2004. Estimates of trace metal bioavailability to human ingesting contaminated oysters. Food and Chemical Toxicology 42: 1893-1902. DOI: 10.1016/j. fct.2004.07.011

Bray, D. J., I. Green, D. Golicher \& R. J. H. Herbert. 2015. Spatial variation of trace metals within intertidal beds of native mussels (Mytilus edulis) and non-native Pacific oysters (Crassostrea gigas): implications for the food web? Hydrobiologia 757: 235-249. D0I: 10.1007/ s10750-015-2255-8

Bryan, G. W. 1971. The effects of heavy metals (other than mercury) on marine and estuarine organisms. Proceedings of the Royal Society of London B 177: 380-410.

Cadena-Cárdenas, L., L. Méndez-Rodríguez, T. Zenteno-Savín, J. García-HerNÁNDEZ \& B. AcostA-VARGAS. 2009. Heavy metal levels in marine mollusks from areas with, or without, mining activities along the Gulf of California, Mexico. Archives of Environmental Contamination and Toxicology 57: 96-102. D0I:10.1007/s00244-008-9236-0

Cheung, Y. H. \&M. H. Wong. 1992. Trace metal contents of the Pacific oyster (Crassostrea gigas) purchased from markets in Hong Kong. Environmental Management 16 (6): 753-761. D0I:10.1007/ BF02645665

Escobedo-URíAs, D. C. 2010. Diagnóstico y descripción del proceso de eutrofización en lagunas costeras del norte de Sinaloa. Tesis Doctoral en Ciencias Marinas. Centro Interdisciplinario de Ciencias Marinas CICIMAR, Instituto Politécnico Nacional, 274 p.

fa0 (Food and Agriculture Organization of the United Nations). 1983. Compilation of legal limits for hazardous substances in fish and fishery products. FAO Fishery Circular No 464, 100 p.

fa0 (Food and Agriculture Organization of the United Nations). 2015. Cultured Aquatic Species Information Programme Crassostrea gigas 
(Thunberg, 1793). Fisheries and Aquaculture Department. Available online at: http://www.fao.org/fishery/culturedspecies/Crassotreagigas/en. (downloaded July 24, 2015).

FDA (Federal Drug Administration). 1993. Guidance Document for Lead in Shellfish. Center for Food Safety and Applied Nutrition United States Food and Drug Administration 200 st., SW Washington, DC, 502 p.

FDA (Federal Drug Administration). 2003. Guide for the Control of MoIluscans Shellfish. National Shellfish Sanitation Program. US Department of Health and Human Services, Public Health Service, Interstate Shellfish Sanitation Conference USA, Washington, DC, $427 \mathrm{p}$.

Frías-Espericueta, M. G., I. Osuna-Páez, I. Bañuelos-Vargas, G. López-López, M. D. Muy-Rangel, G. Izaguirre-Fierro, W. Rubio-Carrasco, P. C. Meza-GueRRERO \& D. Voltolina. 2009. Cadmium, copper, lead and zinc contents of the mangrove oyster, Crassostrea corteziensis, of seven coastal lagoons of NW Mexico. Bulletin of Environmental Contamination and Toxicology 83: 595-599. D0I: 10.1007/s00128-009-9828-Z

Gallo-García, M. C., M. García-Ulloa, D. Godínez-Siordia \& K. Rivera-Gómez. 2001. Estudio preliminar sobre el crecimiento y supervivencia del ostión del Pacífico Crassostrea gigas (Thunberg, 1873) en Barra de Navidad, Jalisco, México. Universidad y Ciencia 17: 83-91.

García-Rico, L., R. E. Ramos-Ruiz \& J. V. Jiménez. 2001. Determination of total metals in cultivated oysters (Crassostrea gigas) from the northwest coast of Mexico by microwave digestion and atomic absorption spectrometry. Journal of AOAC International 84 (6): 1909-1913.

García-Rico, L. L. Tejeda-Valenzuela \& Burgos-Hernández. 2010. Seasonal variations in the concentrations of metals in Crassostrea corteziensis from Sonora, Mexico. Bulletin of Environmental Contamination and Toxicology 85: 209-213. DOI: 10.1007/s00128-010-0055-4

García-Ulloa, M., M. C. Gallo-García, J. T. Ponce-Palafox \& J. L. ArredondoFIGUEROA. 2008. Efecto de la cal en el control de gusanos barrenadores (Polychaete: Spionidae) en un cultivo experimental de ostión variando el tiempo de inmersión y la frecuencia de aplicación. Universidad y Ciencia 24 (2): 125-134.

Gómez-Arroyo, S., C. Martínez-Valenzuela, S. Calvo-González, R. VillalobosPietrinı, S. M. Waliszewski, M. E. Calderón-Segura, A. Martínez-Arroyo, R. Félix-Gastélum \& A. Lagarda-Escarrega. 2013. Assessing the genotoxic risk for mexican children who are in residential proximity to agricultural areas with intense aerial pesticide application. Revista Internacional de Contaminación Ambiental 29 (3): 217-225.

Gorman, M. 1993. Environmental Hazards-Marine Pollution. ABC-CLIO, Inc., (Contemporary World Issues series), Santa Barbara, California. $252 \mathrm{p}$.

Green-Ruiz, C., J. Ruelas-Inzunza \& F. Páez-Osuna. 2005. Mercury in surface sediments and benthic organisms from Guaymas Bay, east coast of the Gulf of California. Environmental Geochemistry and Health 27: 321-329. DOI: 0.1007/s10653-004-5741-x

Hernández-Cornejo, R., N. Koedam, A. Ruiz-Luna, M.Troell \& F. Dahdouh-GueBAS. 2005. Remote sensing and ethnobotanical assessment of the mangrove forest changes in the Navachiste-San Ignacio-Macapule lagoon complex, Sinaloa, Mexico. Ecología y Sociedad 10 (1): 16.
Honorable Ayuntamiento de Guasave. 2016. Guasave, Avanzando Juntos. 2014-2016. Disponible en línea en: http://guasave.gob.mx/sitio/ index.php?option=com_content\&view=article\&id=1573:informac ion-de-guasave\&catid=121:servicios\&ltemid=20 (consultada el 4 de diciembre de 2016).

ineGI ( Instituto Nacional de Geografía e Informática). 2001. Censo Poblacional, México DF, 2000. Disponible en línea en: http://www.inegi.org. mx (consultado el 20 marzo 2015).

Jara-Marini, M. E., M. F. Soto-Jiménez \& F. PÁez-Osuna. 2008. Trace metal accumulation patterns in a mangrove lagoon ecosystem, Mazatlan Harbour, SE Gulf of California. Journal of Environmental Science Health Part A. 43: 995-1005. D0I: 10.1080/10934520802059797

Jara-Marini, M. E., M. F. Soto-Jiménez \& F. Páez-Osuna. 2009. Trophic relationships and transference of cadmium, copper, lead and zinc in a subtropical coastal lagoon food web from SE Gulf of California. Chemosphere 77: 1366-1373. DOI: 10.1016/j.chemosphere.2009.09.025

Jara-Marini, M. E., J. N. Tapia-Alcaraz, J. A. Dumer-Gutiérrez, L. García-Rico, J. Garcia-Hernández \& F. Páez-Osuna. 2013. Comparative bioaccumulation of trace metals using six filter feeder organisms in a coastal lagoon ecosystem of the central-east Gulf of California. Environmental Monitoring and Assessment 185: 1071-1085. D0I:10.1007/ s10661-012-2615-z

Kanthal, L. D., J. F. Gobin, D. M. Beckles, B. Lauckner \& A. Mohammed. 2014. Metals in sediments and mangrove oysters (Crassostrea rhizophorae) from the Caroni Swamp, Trinidad. Environmental Monitoring and Assessment 186: 1961-1976. DOI: 10.1007/s10661-0133510-y

Katayon, S., I. Ahmad, 0. Hishamuddin \& K. MisRi. 2007. Heavy metal depuration in flat tree oysters Isognomon alatus under filed and laboratory conditions. Toxicological \& Environmental Chemistry 86 (3): 171179. DOI: $10.1080 / 02772240400007039$

Lango-Reynoso, F., C. Landeros-Sánchez \& M. R. Castañeda-Chávez. 2010. Bioaccumulation of cadmium $(\mathrm{Cd})$, lead $(\mathrm{Pb})$ and arsenic $(\mathrm{As})$ in Crassostrea virginica (Gmelin, 1791), from Tamiahua lagoon system, Veracruz, Mexico. Revista Internacional de Contaminación Ambiental 26 (3): 201-210.

LE, Q. D., L. G. BACH \& T. ARAl. 2015. Monitoring heavy metal contamination using rocky oyster (Saccostrea glomerata) in Haiphong-Halong Coastal Area, North Vietnam. International Journal of Environmental Research 9: 1373-1378.

LIN, S. \&l. J. HSIEN. 1999. Occurrence of green oyster and heavy metal contamination levels in the Sien-San area, Taiwan. Marine Pollution Bulletin 38: 960-965. D0I:10.1016/S0025-326X(99)00108-3

Lyle-Fritch, L. P., E. Romero-Beltrán\& F. Páez-Osuna. 2006. Survey on use of the chemical and biological products for shrimp farming in Sinaloa (NW Mexico). Aquacultural Engineering 35: 135-146. DOI: 10.1016/j.aquaeng.2005.09.006

Najiah, M., M. Naridah, K. L. Lee, S. W. Lee, W. Wendy, H. H. Ruhil \& F. A. NuRuL. 2008. Bacteria flora and heavy metals in cultivated oysters Crassostrea iredali of Setui Wetland, East Coast Peninsular Malaysia. Veterinary Research Communications 32: 377-381. 
NOM (Norma Oficial Mexicana). 1993. NOM-031-SSA1-1993. Bienes y servicios. Productos de la Pesca. Moluscos bivalvos frescos-refrigerados y congelados. Especificaciones sanitarias. Secretaría de Salud. Gobierno de la República, México DF. Disponible en línea en: http://www.salud.gob.mx/unidades/cdi/nom/027ssa1 (consultado el 14 de abril 2015).

Ochoa, V., C. Barata \& M. Carmen-Riva. 2013. Heavy metal content in oysters (Crassostrea gigas) cultured in the Ebro Delta in Catalonia, Spain. Environmental and Monitoring Assessment 185: 6783-6792. D0l:10.1007/s10661-013-3064z

Okazaki, R. K. \& M. H. Panietz. 1981. Depuration of twelve trace metals in tissue of the oysters Crassostrea gigas and $C$. virginica. Marine Biology 63: 113-120. D0I: 10.1007/BF00406818

Osuna-Martínez, C. C., F. Páez-Osuna \& R. Alonso-Rodríguez. 2010. Mercury in cultured oysters (Crassostrea gigas Thunberg, 1793 and C. corteziensis, Hertlein, 1951) from four coastal lagoons of the SE Gulf of California, Mexico. Bulletin of Environmental Contamination and Toxicology 85: 39-343. D0I: 10.1007/s00128-010-0071-4

Osuna-Martínez, C. C., F. Páez-Osuna \& R. Alonso-Rodríguez. 2011. Cadmium, copper, lead and zinc in cultured oyters under two contrasting climatic conditions in coastal lagoons from the SE Gulf of California. Bulletin on Environmental Contamination and Toxicology 87: 272-275. DOI: 10.1007/s00128-011-0355-3

Páez-Osuna, F. \& C. Marmolejo-Rivas. 1990a. Occurrence and seasonal variation of heavy metals in the oyster Saccrostrea iridescens. BuIletin of Environmental Contamination and Toxicology 44: 129-134. D0I:10.1007/BF01702372

Páez-Osuna, F. \& C. Marmolejo-Rivas. 1990b. Trace metals in tropical coastal lagoon bivalves, Crassostrea corteziensis. Bulletin of Environmental Contamination and Toxicology 45: 538-544. D0I:10.1007/ BF01700626

Páez-Osuna, F. \& C. C. Osuna-Martínez. 2015. Bioavailability of cadmium, copper, mercury, lead, and zinc in subtropical coastal lagoons from the Southeast Gulf of California using mangrove oysters (Crassostrea corteziensis and Crassostrea palmula). Archives of Environmental Contamination and Toxicology 68: 305-316. D0I: 10.1007/ s00244-014-0118-3

Páez-Osuna, F., H. M. Zazueta-Padilla \& G. Izaguirre-Fierro. 1991. Trace metals in bivalves from Navachiste lagoon, México. Marine Pollution Bulletin 22 (6): 305-307. D0I:10.1016/0025-326x(91)90809-7

Páez-0suna, F., A. Gracia, F. Flores-Verdugo, L. P. Lyle-Fritch, R. Alonso-Rodríguez, A. Roque \& A. C. Ruiz-Fernández. 1993. Biochemical composition of the oysters Crassostrea iridescens Hanley and Crassostrea corteziensis Hertlein in the Northwest coast of Mexico: seasonal changes. Journal of Experimental Marine Biology and Ecology 170: 1-9. DOI:10.1016/0022-0981(93)90125-8

Páez-Osuna, F., M. G. Frías-Espericueta \& J. L. Osuna-López. 1995. Trace metal concentration in relation to season and gonadal maturation in the oyster Crassostrea iridescens. Marine Environmental Research 40: 19-31. DOI:10.1016/0141-1136(94)00004-9

Páez-Osuna, F., A. C. Ruiz-Fernández, A. V. Botello, G. Ponce-Vélez, J. I. OsunaLópez, M. G. Frías-Espericueta, G. López-López \& H. M. Zazueta-Padilla.
2002. Concentrations of selected trace metals ( $\mathrm{Cu}, \mathrm{Pb}, \mathrm{Zn}$ ), organochlorines (PCBs, HCB) and total PAHs in mangrove oysters from the Pacific Coast of Mexico: an overview. Baseline/Marine Pollution Bulletin 44: 1296-1313.PII: S0025-326X(02)00172-8

Páez-0suna, F., A. Gracia, F. Flores-Verdugo, L. P. Lyle-Fritch, R. AlonsoRodríguez, A. Roque \& A. C. Ruz-Fernández. 2003. Shrimp aquaculture development and the environment in the Gulf of California ecoregion. Marine Pollution Bulletin 46: 806-815. D0I:10.1016/S0025326X(03)00107-3

Pan, K. \& W.-X. WANG. 2009. Biodynamics to explain the difference of cooper body concentrations in five marine bivalve species. Environmental Science and Technology 43 (6): 2137-2143. D0I:10.1021/ es802888u

PhiLLIPS, D. J. H. \& K. MutTaRASIN. 1985. Trace metals in bivalve mollusks from Thailand. Marine Environmental Research 15: 215-234. DOI:10.1016/0141-1136(85)90003-0

Robinson, W. A., W. A. Maher, F. Krikowa, J. A. Nell \& R. Hand. 2005. The use of the oyster Sacosstrea glomerata as a biomonitor of trace metal contamination: intra-sample, local scale and temporal variability and its implications for biomonitoring. Journal of Environmental Monitoring 7: 208-223. D0l:10.1039/B415295F

Ruiz-Luna, A. \& G. dE LA Lanza-Espino. 1999. Sistemas rurales de producción camaronícola en Guasave, Sinaloa y norte de Nayarit (descripción física, entorno y ubicación). Centro de Investigación, Alimentación y Desarrollo (Unidad Mazatlán) y Universidad Nacional Autónoma de México, México DF. 45 p.

Sagarpa (Secretaría de Agricultura, Ganadería, Desarrollo Rural, Pesca y ALIMENTACIÓN). 2015. Disponible en línea en:www.conapesca.sagarpa.gob.mx/wb/cona/consulta_especifica_por_producción (consultado el 25 de marzo 2016).

Sarong, M. A., C. Jihan, Z. A. Muchlisin, N. Fadi \& S. Sugianto. 2015. Cadmium, lead and zinc contamination on the oyster Crassostrea gigas muscle harvested from the estuary of Lanmyong River, Banda Aceh City, Indonesia. AACL Bioflux 8 (1): 1-6.

Soto-Jiménez, M., F. Páez-Osuna \& F. Morales-Fernández. 2001. Selected trace metals in oysters (Crassostrea iridescens) and sediments from the discharge zone of the submarine sewage outfall in Mazatlan Bay (Southeast Gulf of California): Chemical fractions and bioaccumulation factors. Environmental Pollution 114: 357-370. DOl: 10.1016/S0269-7491(00)00239-6

Vázquez-Boucard, C., G. Anguiano-Vega, L. Mercier \& E. Rojas del Castlllo. 2014. Pesticide residues, heavy metals, and DNA damage in sentinel oysters Crassostrea gigas from Sinaloa and Sonora, Mexico. Journal of Toxicology and Environmental Health A. 77 (4): 169-176. DOI: $10.1080 / 15287394.2013 .853223$

WANG, L. \& W. X. WANG. 2014. Depuration of metals by the green-colored oyster Crassostrea sikamea. Toxicology \& Chemistry 33 (10): 23792385. DOI: 10.1002/etc. 2695

Wong, M. H., C. K. Choy, W. M. Lau \& Y. H. Cheung. 1981. Heavy-metal contamination of the Pacific oysters (Crassostrea gigas) cultured in Deep Bay, Hong Kong. Environmental Research 25: 302-309. D0I:10.1016/0013-9351(81)90032-3 